\title{
IMPROVEMENT OF RABBIT PASTEURELLOSIS VACCINE USING MONTANIDE ISA50
}

\author{
ELHAM A. YOUSSEF AND HODA E. TAWFIK
}

Veterinary Serum and Vaccine Research Institute, ARC, Ministry of Agriculture, Dokki, Giza

(Manuscript received 24 December 2010)

\begin{abstract}
Montanide ISA50 was used as an adjuvant for preparation of inactivated rabbit pasteurellosis vaccine, and compared with the commercially produced oil inactivated rabbit pasteurellosis vaccine adjuvanted with mineral oil. Two groups of rabbits were inoculated separately by first dose of these vaccines followed by second dose after 21 days from the first dose, the mineral oil used for first group and ISA50 used for the second group as adjuvant, meanwhile, the third group was left as non-vaccinated control group.

Cellular immunity was evaluated by using cell proliferation test and macrophage activity test (phagocytic percentage, phagocytic index). Humoral immune response was evaluated by using indirect haemagglutination test (IHA) and enzyme linked immunosorbent assay (ELISA). The results of the aforementioned tests proved that the two types of adjuvant induced protective titre against the diseases, but Montanide ISA50 oil adjuvant gave higher and longer duration of antibody level than the mineral oil. Challenge test and protection test in rabbit and mice gave similar results.
\end{abstract}

\section{INTRODUCTION}

Pasteurellosis due to Pasteurella multocida is an important disease in both commercial rabbit farm, as well as in laboratories using rabbits for research purposes. A variety of clinical signs and lesions have been associated with such $P$. multocida infection in the domestic rabbit. Snuffles due to rhinitis, chronic bronchopneumonia and acute fibrinous bronchopneumonia are patterns of diseases seen in the respiratory tract. Conjunctivitis, purulent otitis media, localized absessation, genital tract infection and septicemia are all patterns of diseases associated with pasteurella infection. So commercial rabbitries are exposed to economic losses due to pasteurellosis (Mukkur et al., 1982).

A variety of procedures have been used to reduce or eliminate pasteurellosis in rabbitries, including the establishment of pasteurella-free colonies, elimination of carrier by repeated culture of nasal swap sampling for Pasteurella multocida and vaccination with an inactivated vaccine (Mukkur et al., 1982).

Mineral oil emulsions have been widely used to produce a prolonged slow release of antigen from aqueous phase. They have been used with antigen to potentiate the antibody response, also, to prolong their action (Cox and Coulter, 1997, 
Aucoutuies et al., 2001). Tween-80 is known to cause reduction in viscosity, interfacial tension in coagulation rate of aqueous globules of water in oil emulsion (Chiejina and Sowell, 1974).

Montanide ISA50 adjuvant is characterized by high effectiveness in generating strong immune response, easily manufactured with smooth, abscess free, stable and safe at storage (Seppic, 1994).

The purpose of this study was designed to use Montanide ISA50 adjuvant for preparing rabbit pasteurella vaccine in a trial to improve immune response of rabbits to pasteurellosis in comparison to the ordinary mineral oil adjuvanted vaccine.

\section{MATERIALS AND METHODS}

A virulent local strain of $P$. multocida serotype A \& D were obtained from Aerobic Bacterial Department, Veterinary Serum and Vaccine Research Institute, Abbasia, Cairo. These serotypes were used for production of commercial and our experimental $P$. multocida vaccine, serological tests as well as challenge test.

\section{Laboratory animals}

Healthy fifty rabbits with an average body weight of $2.5-2.5 \mathrm{~kg}$ were obtained from private farm and kept under strict hygienic measures. These rabbits were proved to be fully susceptible to the $P$. multocida by serological testing of all serum samples.

White mice with an average weight of $18 \mathrm{~g}$ were used for determination of the protective value of the two different adjuvanted vaccines according to Ose and Muenster (1968).

\section{Adjuvants}

1. Oil adjuvant ISA50: It was obtained from SEPPIC Cosmetics, Pharmacy Division, Paris, France. The ratio of adjuvant to the antigen (Volume / Volume) was done according to manufacturer instructions.

2. Mineral oil: The product of MICBIL, Alexandria, Whiterex 305, May 400 was used.

\section{Emulsifiers}

- Sorbitan monoleate (Span 80 ) was supplied by Ubichem LTD.

- Polyxythene sorbitan (Tween 80 ) was supplied by Sigma Company, USA.

\section{$P$. multocida propagation, titration and inactivation}

Each serotype of $P$. multocida A \& D was propagated separately in trypticase Soya broth at $37^{\circ} \mathrm{C}$ aerobically for 24 hours to obtain a dense culture containing approximately $3.25 \times 10^{10} \mathrm{cfu} / \mathrm{ml}$ of each strain. After 18-24 hours, inactivation was done by addition of $0.25 \%$ formalin, each culture was tested for purity, safety and sterility as mentioned by Mukkur et al. (1982), then, equal amounts of culture were 
mixed and preserved in $0.01 \%$ of thiomersal and stored at $4^{\circ} \mathrm{C}$ until preparation of vaccines emulsion.

\section{Preparation of inactivated $\boldsymbol{P}$. multocida vaccines}

1. Preparation of inactivated $\boldsymbol{P}$. multocida vaccine using mineral oil It was prepared according to Stone et al. (1978).

\section{Preparation of inactivated vaccine using Montanide ISA50}

The vaccine was prepared by mixing $50 \mathrm{ml}$ of $P$. multocida serotypes with $50 \mathrm{ml}$ of Montanide ISA50 (volume/volume) according to manufacturer instructions.

\section{Quality control of the vaccines}

Quality control including purity, sterility and safety tests was carried out according to the Code of American Federal Regulation (1985).

\section{Characterization of the vaccines}

For evaluation of the emulsification process of the vaccines drop test, emulsion viscosity and emulsion stability were done according to Becher (1965).

\section{Efficacy of the two prepared vaccines}

The following tests were traced to verifying the efficacy of the two prepared vaccines:

\section{Evaluation of cell mediated immune response \\ a. Cell proliferation test}

Using proliferation kit with XTT reagent according to Scudiero et al. (1988).

\section{b. Macrophage activity test}

It was performed by the method of Barry et al. (1988), which was modified by El-Enbawy (1990).

\section{Phagocytic percentage $=$}

No. of phagocytes which ingest candida

Total no. of phagocyte

\section{Phagocytic index $=$}

Total no. of phagocytes which ingest more than two candida

Total no. of phagocyte which ingest candida

\section{Evaluation of humoral immunity}

It depends on several serological tests as follows:

\section{a. Indirect haemagglutination test (IHA)}

This test was conducted to determine the antibody titre against $P$. multocida as mentioned by Carter and Rappy (1962). 


\section{b. Enzyme Linked immunosorbent assay (ELISA)}

It was done for determination of antibodies of $P$. multocida by the method of Briggs and Skeels (1984).

\section{Challenge test}

Fifty vaccinated and control rabbits were challenged with $0.1 \mathrm{ml}$ of $100 L_{50}$ of virulent $P$. multocida serotypes A \& D 15, days post-boostering. Observation period was 15 days post-challenge and any mortality was recorded.

\section{Determination of log protection (in mice)}

According to Ose and Muenster (1968).

\section{Experimental Design}

Rabbits were divided into 3 groups as shown in the following table:

Table 1. Experimental schedule.

\begin{tabular}{|c|c|c|c|}
\hline Groups & Group (1)* & Group (2)** & Group (3) *** \\
\hline $1^{\text {st }}$ vaccinal dose (S/C) & $1 \mathrm{ml}$ & $1 \mathrm{ml}$ & Non \\
\hline Blood collection & \multicolumn{2}{|c|}{ From the first week post-vaccination till 16 weeks } \\
\hline $\begin{array}{c}2^{\text {nd }} \text { vaccinal dose (booster dose) } 3 \\
\text { weeks post } 1^{\text {st }} \text { dose S/C }\end{array}$ & $1 \mathrm{ml}$ & $1 \mathrm{ml}$ & Non \\
\hline Challenge test & Challenge by using virulent strain of $P$. multocida serotypes S/C 15 \\
\hline \multicolumn{3}{|c|}{ days post-boostering } \\
\hline
\end{tabular}

* Group (1): Rabbit vaccinated with rabbit pasteurellosis vaccine adjuvanted with mineral oil

** Group (2): Rabbit vaccinated with rabbit pasteurellosis vaccine adjuvanted with Montanide ISA50

*** Group (3): Unvaccinated rabbits (Control)

\section{RESULTS AND DISCUSSION}

Pasteurellosis is one of the most common diseases in rabbits and results in heavy economic losses in rabbitries. Control of that disease is still as subjected of interest and usually attract the attention of researchers to know more and more about the disease epidemiology and how to control it in rabbits.

Vaccination is still considered as one of the major tools for controlling the disease. Vaccine efficacy depends on many variables, such as the nature, the amount of antigen administrated and the presence of adjuvants to enhance immunogenicity (Stone et al., 1978).

Adjuvant is a substance that when added to a vaccine will enhance immunogenicity of an antigen, in the stimulation and evolution of humoral immune response. In some instances adjuvants also stimulate a cell mediated response by trapping antigen at sites where they are accessible to reactive lymphocytes, and they 
induce antigen presenting cells to express costimulatory molecules such as $\mathrm{CD}_{80}$. Also, adjuvant can reduce the quantity of antigen needed to generate a protective immune response and enables the vaccine to be cheaper, they can prolong the immune response of the vaccinated animals and birds (Stewart-Tull, 1994 and Aucoutuies et al., 2001).

In this study, we compare between two types of adjuvants (Montanide ISA50 and mineral oil) for improving the immune response of rabbit against rabbit pasteurellosis.

The data given in Table 2 showed the cellular immune response of rabbit vaccinated with 2 different adjuvanted vaccines in which the phagocytic percentage and index gave high activity through the days. There was noticeable difference between vaccinated groups and control (non-vaccinated) group. The results agree with Amal et al. (2005, Elham and Mervat 2006). They found that the vaccine prepared with Montanide ISA50 oil adjuvant appeared to be more potent and gave protective level up to 6 months in comparison with the commercially used vaccine that contains mineral oil and gave protection up to 4 months only.

The results in Table 3 indicated that the lymphocytes proliferation revealed the gradual increase for different groups till 21 days post- vaccination, but there was a decrease in values in group I (vaccine adjuvanted with mineral oil) at 28 days.

Humoral immune response of $P$. multocida was determined by IHA test (Table 4) and ELISA (Table 5). These tests showed that the earlier, good immune response and higher antibodies against $P$. multocida occurred in second group of rabbits which received vaccination of $P$. multocida vaccine containing oil ISA50 than first group which received vaccination with the same vaccine adjuvanted with mineral oil from first week post- vaccination (WPV) till the end of experiment. These results agreed with William and Johon (1989), Seppic (1994), Abdel Wanis et al. (2003), Amal et al. (2005) and Elham and Mervat (2006).

The results of challenge test against $P$. multocida tabulated in Table 6 proved that Montanide ISA50 adjuvanted vaccine gave protection $100 \%$ percent and $90 \%$ against serotypes $A \& D$, respectively, while, mineral oil gave $80 \%$ and $80 \%$ protection against serotypes $A \& D$, respectively. These results were in agreement with Amal et al. (2005), Elham and Mervat (2006).

Also, the protective value of the 2 different adjuvant vaccines was determined by the log protection in mice which showed that the log protection of Montanide ISA50 adjuvanted vaccine was 3.85 and 3.69 for types $A \& D$, respectively, while, the log protection of mineral oil adjuvanted vaccine was 3.15 and 2.98 for types $A \& D$, respectively (Table 7). 
So, the results of the present study concluded that both types of adjuvanted vaccines induced a considerable immunity in rabbits, but, Montanide ISA50 gave higher and long duration of antibodies response and protection in addition to its preparation with an easier technique.

Table 2. Evaluation of cell mediated immune response in different rabbits of vaccinated groups by macrophage activity using candida albicans expressed by phagocytic percentage and phagocytic index.

\begin{tabular}{|c|c|c|c|c|c|c|}
\hline \multirow{2}{*}{$\begin{array}{c}\text { Groups of } \\
\text { rabbits }\end{array}$} & \multicolumn{3}{|c|}{ Phagocytic percentage } & \multicolumn{3}{c|}{ Phagocytic index } \\
\cline { 2 - 7 } & \multicolumn{3}{|c|}{ Days post vaccination } & \multicolumn{3}{c|}{ Days post vaccination } \\
\cline { 2 - 7 } & 7 & 14 & 21 & 7 & 14 & 21 \\
\hline 1 & 77.78 & 84.62 & 58.33 & 0.86 & 0.82 & 0.71 \\
\hline 2 & 71.43 & 89.46 & 87.50 & 0.80 & 0.86 & 0.79 \\
\hline 3 & 13.90 & 14.10 & 13.10 & 0.09 & 0.06 & 0.06 \\
\hline
\end{tabular}

Group (1): Rabbits vaccinated with rabbit pasteurellosis vaccine adjuvanted with mineral oil.

Group (2): Rabbits vaccinated with rabbit pasteurellosis vaccine adjuvanted with Montanide ISA50.

Group (3): Non-vaccinated rabbits (Control).

Table 3. Lymphocytic proliferation test for vaccinated rabbit groups expressed by optical density.

\begin{tabular}{|c|c|c|c|c|}
\hline \multirow{2}{*}{$\begin{array}{c}\text { Groups of } \\
\text { rabbits }\end{array}$} & \multicolumn{4}{|c|}{ Optical Density } \\
\cline { 2 - 5 } & \multicolumn{4}{|c|}{ Days post vaccination } \\
\cline { 2 - 5 } & 7 & 15 & 21 & 28 \\
\hline 1 & 0.458 & 0.460 & 1.08 & 0.547 \\
\hline 2 & 0.425 & 0.350 & 0.848 & 0.903 \\
\hline 3 & 0.112 & 0.097 & 0.125 & 0.123 \\
\hline
\end{tabular}

Group (1): Rabbits vaccinated with rabbit pasteurellosis vaccine adjuvanted with mineral oil.

Group (2): Rabbits vaccinated with rabbit pasteurellosis vaccine adjuvanted with Montanide ISA50.

Group (3): Non-vaccinated rabbits (Control). 
Table 4. Comparative results of anti-Pasteurella multocida antibodies in sera of rabbits vaccinated with $P$. multocida vaccine using different adjuvants measured by IHA test.

\begin{tabular}{|c|c|c|c|c|c|c|c|c|c|c|c|c|}
\hline \multirow{2}{*}{ Type of adjuvanted vaccine } & \multirow{2}{*}{$\begin{array}{l}\text { Type of } \\
\text { antigen }\end{array}$} & \multirow{2}{*}{ Pre-vaccination } & \multicolumn{10}{|c|}{ Weeks post vaccination } \\
\hline & & & 1 & 2 & 3 & 4 & 6 & 8 & 10 & 12 & 14 & 16 \\
\hline \multirow{2}{*}{$\begin{array}{l}\text { Rabbits vaccinated with } P \text {. multocida } \\
\text { vaccine adjuvanted with mineral oil }\end{array}$} & A & 8 & 52 & 160 & 510 & 780 & 1650 & 1730 & 1580 & 1390 & 985 & 598 \\
\hline & D & 7 & 49 & 140 & 500 & 720 & 1590 & 1750 & 1520 & 1310 & 940 & 509 \\
\hline \multirow{2}{*}{$\begin{array}{l}\text { Rabbits vaccinated with } P \text {. multocida } \\
\text { vaccine adjuvanted with Montanide } \\
\text { ISA50 }\end{array}$} & A & 8 & 92 & 298 & 988 & 1385 & 2350 & 2490 & 2385 & 2240 & 1610 & 1120 \\
\hline & D & 8 & 88 & 289 & 890 & 1250 & 2290 & 2418 & 2370 & 2205 & 1590 & 1080 \\
\hline \multirow{2}{*}{ Control unvaccinated group } & A & 8 & 8 & 9 & 9 & 8 & 9 & 10 & 10 & 9 & 7 & 8 \\
\hline & D & 7 & 8 & 9 & 8 & 9 & 8 & 9 & 10 & 9 & 8 & 8 \\
\hline
\end{tabular}


Table 5. Comparative results of anti-Pasteurella multocida antibodies in sera of rabbits vaccinated with P. multocida vaccine using different adjuvants measured by ELISA.

\begin{tabular}{|c|c|c|c|c|c|c|c|c|c|c|c|c|}
\hline \multirow{2}{*}{ Type of adjuvanted vaccine } & \multirow{2}{*}{$\begin{array}{l}\text { Type of } \\
\text { antigen }\end{array}$} & \multirow{2}{*}{ Pre-vaccination } & \multicolumn{10}{|c|}{ Weeks post vaccination } \\
\hline & & & 1 & 2 & 3 & 4 & 6 & 8 & 10 & 12 & 14 & 16 \\
\hline \multirow{2}{*}{$\begin{array}{l}\text { Rabbits vaccinated with } P \text {. multocida } \\
\text { vaccine adjuvanted with mineral oil }\end{array}$} & A & 85 & 180 & 540 & 2180 & 3120 & 4250 & 4420 & 3150 & 3010 & 2030 & 1730 \\
\hline & D & 87 & 140 & 520 & 2120 & 3109 & 4210 & 4480 & 3170 & 3050 & 2005 & 1680 \\
\hline \multirow{2}{*}{$\begin{array}{c}\text { Rabbits vaccinated with } P \text {. multocida } \\
\text { vaccine adjuvanted with Montanide } \\
\text { ISA50 }\end{array}$} & A & 87 & 290 & 950 & 3750 & 4490 & 6530 & 4930 & 5620 & 5480 & 4570 & 3250 \\
\hline & D & 86 & 280 & 910 & 3650 & 4485 & 6420 & 4900 & 5590 & 5350 & 4320 & 3035 \\
\hline \multirow{2}{*}{ Control unvaccinated group } & A & 85 & 88 & 90 & 95 & 94 & 95 & 92 & 93 & 90 & 88 & 89 \\
\hline & D & 87 & 90 & 90 & 93 & 93 & 90 & 90 & 88 & 87 & 89 & 88 \\
\hline
\end{tabular}


Table 6. Results of challenge test against virulent Pasteurella multocida 6 weeks post-first vaccination.

\begin{tabular}{|c|c|c|c|c|c|}
\hline $\begin{array}{c}\text { Type of adjuvanted } \\
\text { vaccine }\end{array}$ & $\begin{array}{l}\text { Challenge } \\
\text { antigen }\end{array}$ & $\begin{array}{l}\text { No. of } \\
\text { rabbits }\end{array}$ & $\begin{array}{l}\text { No. of } P \text {. } \\
\text { multocida } \\
\text { specific } \\
\text { mortality }\end{array}$ & $\begin{array}{l}\text { No. of mortality } \\
\text { / Total }\end{array}$ & Protection \% \\
\hline \multirow{2}{*}{$\begin{array}{l}\text { Rabbits vaccinated } \\
\text { with } P \text {. multocida } \\
\text { vaccine adjuvanted } \\
\text { with mineral oil }\end{array}$} & A & 10 & 2 & $2 / 10$ & $80 \%$ \\
\hline & D & 10 & 2 & $2 / 10$ & $80 \%$ \\
\hline \multirow{2}{*}{$\begin{array}{c}\text { Rabbits vaccinated } \\
\text { with } P . \text { multocida } \\
\text { vaccine adjuvanted } \\
\text { with Montanide ISA50 }\end{array}$} & A & 10 & 1 & $1 / 10$ & $90 \%$ \\
\hline & D & 10 & 0 & $0 / 10$ & $100 \%$ \\
\hline \multirow{2}{*}{$\begin{array}{l}\text { Control unvaccinated } \\
\text { group }\end{array}$} & A & 5 & 5 & $5 / 5$ & $0 \%$ \\
\hline & D & 5 & 5 & $5 / 5$ & $0 \%$ \\
\hline
\end{tabular}

Table 7. Protective value of rabbit pasteurellosis vaccine using different adjuvants estimated in white mice*.

\begin{tabular}{|c|c|c|}
\hline \multirow{2}{*}{ Challenge } & \multicolumn{2}{|c|}{ Mice immunized with $P$. multocida vaccine adjuvanted with the following adjuvants } \\
\cline { 2 - 3 } serotypes & Mineral oil adjuvant & \multicolumn{2}{|c|}{ Montanide ISA50 adjuvant } \\
\hline A & $3.15 * *$ & \\
\hline D & $2.98 * *$ & \\
\hline
\end{tabular}

* Protective value in logs protection

by Ose and Muenster (1968).

$* *$ Protective value $\geq 2 \log$ 


\section{REFERENCES}

1. Abdel Wanis, N.A., M. Abo El-Khair, M.S. Madkour and A.M. Daoud. 2003. Preparation of EDS vaccine using different adjuvants. J. Egypt. Vet. Med. Assoc., 63 (1): 63-73.

2. Amal, I.M., A.M. Daoud and Fekria El-Bourdiny. 2005. Preparation of inactivated infectious bronchitis virus disease vaccine using new oil adjuvant private. Vet. Med. J. Giza, 53 (2): 329-339.

3. Aucoutuies, J., L. Dupuis and V. Ganne. 2001. Adjuvants designed for veterinary and human vaccines. Vaccine, 19 (17-19): 2666-2672.

4. Barry, Ghamon, R. John and Elisson. 1988. In-vitro microbial activity of avian peritoneal macrophages. Avi. Dis., 33: 177-181.

5. Becher, P. 1965. Theory of emulsion stability: in P. Becher (Ed). Emulsion: Theory and practice. 2nd ed. Rheinold Publishing Corporation. New York, pp. 95-149.

6. Briggs, D.J. and J.K. Skeels. 1984. As enzyme linked immunosorbent assay for detecting antibodies to P. multocida in chicken. Avian Dis., 28 (1): 208-215.

7. Carter, G.R. and E.D. Rappy. 1962. Formalinized erythrocytes in haemagglutination test for typing Pasteurella multocida. Brit. Vet. J., 11: 289-292.

8. Chiejina, S.N. and M.M.H. Sewell. 1974. The release of soultes from the aqueous phase of mineral oil emulsions. Res. Vet. Sci., 17: 312-319.

9. Code of American Federal Regulation. 1985. Published by the Office of the Federal Register National Archives Records Service. General Services Administration (1985).

10. Cox, J.C. and A.R. Coulter. 1997. Adjuvants. A. Classification and review of their modes of action. Vaccine, 15 (3): 248-256.

11. El-Enbawy, M.I. 1990. Some studies on candida albicans. Thesis Ph.D., Fac. Vet. Med., Cairo Univ.

12. Youssef, Elham A. and Mervat A. El-Koffy. 2006. Trials for preparation of combined vaccines against fowl cholera, Newcastle, infectious bronchitis and egg drop syndrome diseases in chickens using Montanide ISA50 oil. J. Egypt. Vet. Med. Assoc., 66 (1): 181-195.

13. Mukkur, T.K.S., N.A. Pyliotis and A. Bones. 1982. Possible immunological synergism among the protective antigens of P. multocida type A. Comp. Pathol., 92: 249-260. 
14. Ose, M.S. and B.S. Muenster. 1968. Method for evaluation of vaccines containing Pasteurella multocida. Am. J. Vet. Res., 29 (9): 1863-1866.

15. Scudiero, D.A., R.H. Shoemaker, K.D. Paill, A. Monks, S. Tierney, T.H., M.J. Nofziger, Currens, D. Seniff and M.R. Boyd. 1988. Evaluation of soluble tetrazolium/formazan assay for cell growth and drug sensitivity in culture using human and other tumor cell lines. Cancer Res., 98: 4827-4833.

16. Seppic. 1994. Montanide and Montanide ISA adjuvants for vaccines. Technical Bulletin, Seppic, Paris.

17. Stewart-Tull, D.E.S. 1994. The theory and practical application of adjuvants. Wibey, Chichester and New York.

18. Stone, D., M. Brugh, S.R. Hophins, H.W. Yoder and C.W. Peard. 1978. Preparation of inactivated oil emulsion vaccines with avian viral or mycoplasma antigens. Avi. Dis., 22: 666-674.

19. William, T.D. and W.D. John. 1989. The response of broiler breeder chicken to parenteral administration of avirulent P. multocida. Avian Dis., 24 (3): 743-750. 


\section{تطوير لقاح التسمم الدموى الأرنبى باستخدام المونتانيد أى أسط}

\section{إلهام علام يوسف، هلى إبراهيم توفيق}

معهة بحوث الأمصال و اللقاحات البيطرية - مركز البحوث الزراعبة وزارة الزراعة - الدقى - الجيزة

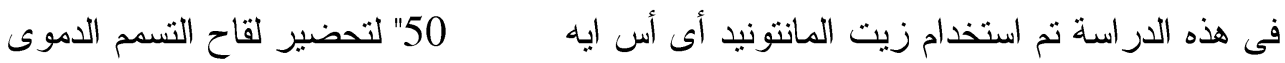
الأرنبى لمقارنته مع نفس اللقاح المحضر محلياً والذى استخدم فيه الزيت المعدنى كمحفز مناعى، حيث لهيث

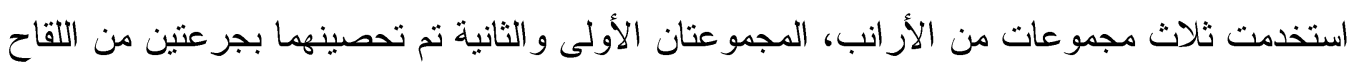

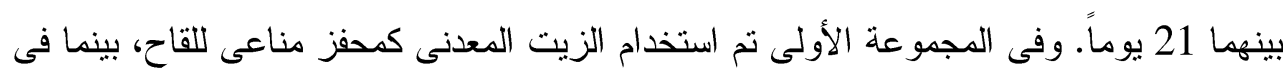
المجموعة الثانية تم استخدام زيت المانتونيد أى أس أيث50" كمحفز مناعى للقاح، أما المجموعة الثالثالثة فقد تركت كمجموعة ضابطة (كنترول) أى غير محصنة تماماً.

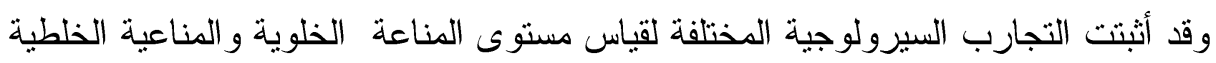

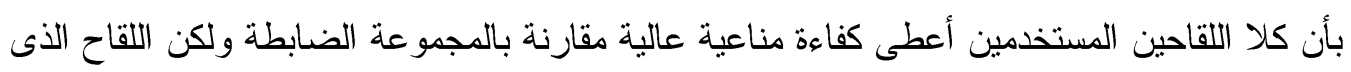
استخدم فيه المانتونيد أى أس أيه50" كمحفز مناعى أعطى أعلى مستوى مناعى من الأجسام المضادة و أطول فترة مناعية مقارنة باللقاح الذى احتوى الزيت المعدنى كمحفز مناعى وقد تم تأكيد هذه النتائج

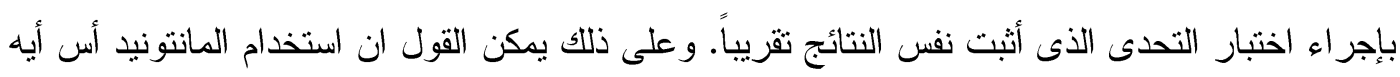
50" كمحفز مناعى يعطى أفضل كفاءة مناعية فى الأرانب. 